\title{
SOLUTION-ORIENTED EVALUATION OF FAMILY RELATIONS AND SCHOOL RELATIONS OF CHILDREN WITH LOW SCHOOL SUCCESS IN THE CONTEXT OF PARENTS AND CHILDREN
}

\author{
Merve Gül Seçgin ${ }^{1 i}$, \\ Şengül İlgar ${ }^{2}$ \\ 1PhD Student, \\ Department of Classroom Teaching, \\ Graduate Education Institute, \\ İstanbul University, \\ Cerrahpaşa, Turkey \\ ${ }^{2}$ Associate Professor, \\ Basic Education Department, \\ Hasan Ali Yücel Faculty of Education, \\ İstanbul University, \\ Cerrahpaşa, Turkey
}

\begin{abstract}
:
This study was aimed to examine the relationships of children with low school success with their parents in the context of mother, father and child. The study group of the study consisted of children, who graduated from the fourth grade of primary school and whose school success was low, and their parents. The data were collected using the interview and mind map technique. According to the data obtained from the research, most of the mothers' center themselves in the relationship with their children and evaluate their children with their behaviors. In school relations, it is seen that the responsibility of the child is generally with the mother and the fathers remain in the background. While some of the mothers advised their children to study when the children received low grades, some mothers expressed their desperation in this regard. It has been revealed that some fathers do not care that their children get low grades. It is seen that the solution is for the parents who are waiting for the teacher. It has been revealed that parents do not produce concrete solutions for school problems and low grading. It was observed that the highest frequency in the associations of children with their parents belonged to the love code.
\end{abstract}

Keywords: primary school students, school success, school failure, family relations, parental attitudes

'Correspondence: email merve.secgin24@gmail.com 


\section{Özet:}

$\mathrm{Bu}$ araştırmada, okul başarısı düşük olan çocukların ebeveynleriyle ilişkilerinin anne, baba ve çocuk bağlamında incelenmesi amaçlanmıştır. Araştırmanın çalışma grubunu ilkokul dördüncü sınıftan mezun olmuş, okul başarısı düşük çocuklar ve onların ebeveynleri oluşturmuştur. Veriler görüşme ve zihin haritası tekniği kullanılarak toplanmıştır. Araştırmadan elde edilen verilere göre; annelerin çoğu çocuğuyla olan ilişkide kendisini merkeze alıp, çocuğunu kendisine olan davranışlarıyla değerlendirmektedir. Okul ilişkilerinde genel olarak çocuğun sorumluluğunun annede olduğu ve babaların daha geri planda kaldığı görülmektedir. Çocuklar düşük not aldıkları zaman annelerin bazıları çocuklarına ders çalışmalarına yönelik telkin verirken, bazı anneler bu konuda çaresizliklerini dile getirmişlerdir. Bazı babaların ise çocuklarının düşük not almasını umursamadıkları ortaya çıkmıştır. Çözümü öğretmenden bekleyen anne, babalara olduğu görülmektedir. Okul problemlerinde ve düşük not alma konusunda ebeveynlerin somut çözümler üretmedikleri ortaya konmuştur. Çocukların ebeveynleriyle ilgili çağrışımlarında en yüksek frekansın sevgi koduna ait olduğu görülmüştür.

Anahtar kelimeler: İlkokul öğrencileri, okul başarısı, okul başarısızlığı, aile içi, ilişkiler, ebeveyn tutumları

\section{Introduction}

One of the most important aspects that make people special is that they are open to communication. It is a social entity due to human creation. This feature causes people to constantly develop relationships. This network of relationships begins to develop while the person is still in the womb. This process continues to increase and diversify with birth. Although school-aged children have created new relationship networks with teachers and peers, the people they are most in contact with continuing to be their parents. Teachers can often determine the direction of relationships in the family by observing children. This can sometimes affect the child's daily performance and sometimes affect the general mood. Giving emotional support to the individual allows him/her to trust himself/herself and other individuals, to feel love, to gain identity, to develop personality, to develop social skills and to socialize.

The structure of the family, communication within the family, mutual respect and cooperation play an important role in the fulfillment of these functions of the family. Boundaries, roles and relationships in the family, distribution of authority create the emotional power necessary for harmony and continuity. Factors such as resilience or rigidity, proximity or distance, regular irregular communication or non-communication in family relationships closely affect the basic needs and developmental needs of family life and problem-solving. The positive attitudes of the parents allow the child to develop a unique self. It ensures that the child is an individual with high self-esteem, a developed sense of responsibility and self-control. On the other hand, negative attitudes, self- 
esteem, level of assertiveness, low independence and internal control may result in high levels of aggression and insecurity.

It can be said that especially children who have problems in family relationships carry this to school and classroom. It is considered important to discuss the relationships of children with low school success with their parents. This has a critical value both for the creation of a healthy educational environment in the classroom and for the psychological balance of the student. It is mentioned that social relations and establishing a healthy commitment are necessary for psychological well-being with the concept of "being related", which is discussed in the self-determination theory.

Success is the indicator of the extent to which the student benefits from the course or educational programs in the school environment or the achievement of the desired result. It is the expression of skills and/ or acquired knowledge determined by grades, test scores or both. It is the difference between the student's low grades below his/her capacity and the student's actual capacity (Carter \& Good, 1973; Garbarino, 1985). However, instead of evaluating the capacity of children in school with exam results alone, it would be correct to examine the factors affecting success, temporarily, permanently, internally, externally (Özabacı \& Acat, 2005).

There are many factors affecting student success in school. The causes of school failure can be summarized under the following main headings:

1) Personal factors;

2) Family-related factors;

3) Factors related to the group of friends;

4) School and teacher factor. (cited in Sar1, 2012; Tezcan, 1985; Mandel \& Marcus, 1988: Özabacı \& Acat, 2005)

While failure leads to a lack of self-confidence and labeling in the child, it also prevents its development. At the same time, it may cause him/her to develop negative feelings towards his/her family, school and friends, while also disrupting his/her relationships. While causing them to be maladaptive, they can cause problem behaviors and even guilt (Eripek, 1982; Kızmaz, 2004).

Families make a significant contribution to the success of their children by establishing a healthy communication with their children and by cooperating with schools and teachers (Çelenk, 2003; Aslan, 1994). In the education of their children, parents' interest and continuous efforts in the education of children increase academic achievement, school environment and course learning. This was found to be the case in primary school students (Driessen, Smith, \& Sleegers, 2005; Pena 2000 \& Dearing, Kreider, Simpkins \& Weiss, 2006).

Family and home environment, relationships between family members and parental attitude are also important factors in student success (Tatlllığlu \& Korkmaz, 2015). Theorists and researchers emphasize the attitudes of parents and the activities they participate in for the education of their children, and state that positive attitudes towards education and school cause increased school performance of children (Rimm-Kaufman, Pianta, Cox and Bradley, 2000, cited in: Şengönül, 2019). Arcan (2006) pointed out that 
the democratic attitudes and behaviors of parents positively affect the success of their children. Erdoğdu (2007) stated that mothers' democratic attitudes positively affect the child's school success and that they support school work by taking care of the child's development.

In his study on primary school students, Hakan (2001) found that students with high academic success went to the school of their children more frequently, took care of their children closely and offered a suitable educational environment to their children, and that their relationships with teachers were good. It has been revealed that the parents of the unsuccessful students are not sufficiently interested in their children's education and cannot prepare the support and environment that will ensure success at home.

Based on what was written, in this study, the answer to the question of how children with low school success are related to their parents was sought.

\section{Purpose and Method}

This study was aimed to examine the relationships of children with low school success with their parents in the context of mother, father and child. For this purpose, answers to the following questions were sought:

1) How do the parents of children with low school success define their relationship with their children?

2) How do children with low school success define their relationships with their families?

It is hoped that the results obtained will contribute to raising awareness about the relationships of children with low school success with their parents and to the positive structuring of their relationships.

\subsection{Research Model}

This research was modeled according to the case study, which is one of the qualitative research methods. Considering the case studies, it is seen that one or more cases are investigated in depth. In the case study, factors such as environment, people, events, processes, etc. are considered as a whole and how they are affected by the existing situation is examined (Yıldırım and Şimşek, 2016). The aim of this study is to examine in detail the relationships of children with low school success with their parents. In order to achieve this goal, this relationship has been addressed and analyzed not only from the perspective of the child but also from the perspective of the mother and father. Therefore, the single state pattern intertwined with the state patterns was used in this study.

\subsection{Research Group}

The criterion sample was used to form the study group of the research. 10 children with low school success and the parents of these children constituted the study group. Thus, the study group consisted of 30 people in total. As the study group, students graduated from 4 th grade were selected. The reason for the selection of 4 th grade students is that 
the evaluation of the student starts at this grade level with the exam in Turkish National Education. In previous classes, exams are not used to evaluate the success of the student. Fourth grade students with a mean score of 54 and below were selected as the criteria for school failure. This criterion corresponds to 2 and 1 in the 5-point grading system. Students whose native language is Turkish were included in the study in order to establish healthy communication and interview, therefore foreign students were not included. Inclusion group students and students with special needs were also excluded from the study.

Of the 4th grade students with low success included in the study, 2 were male and 8 were female. Detailed information about the parents of the students in the study group is given in Table 1:

Table1: Demographic Characteristics of Students' Parents

\begin{tabular}{|l|l|l|l|l|l|l|l|}
\hline $\begin{array}{l}\text { Participants } \\
\text { Male students } \\
(\mathbf{n}=\mathbf{2}) \\
\begin{array}{l}\text { Female students } \\
(\mathbf{n}=\mathbf{8})\end{array}\end{array}$ & $\begin{array}{l}\text { Mother's } \\
\text { Age }\end{array}$ & $\begin{array}{l}\text { Father's } \\
\text { Age }\end{array}$ & $\begin{array}{l}\text { Number } \\
\text { of } \\
\text { Children }\end{array}$ & $\begin{array}{l}\text { Mother's } \\
\text { Educational } \\
\text { Status }\end{array}$ & $\begin{array}{l}\text { Father's } \\
\text { Educational } \\
\text { Status }\end{array}$ & $\begin{array}{l}\text { Mother's } \\
\text { Occupation }\end{array}$ & $\begin{array}{l}\text { Father's } \\
\text { Occupation }\end{array}$ \\
\hline & $\begin{array}{l}\text { Between } \\
\text { the ages } \\
\text { of 20-30 } \\
(\mathrm{n}=2)\end{array}$ & $\begin{array}{l}\text { Between } \\
\text { the ages } \\
\text { of 30-40 } \\
(\mathrm{n}=3)\end{array}$ & $\begin{array}{l}\text { Two } \\
\text { Children } \\
(\mathrm{n}=4)\end{array}$ & $\begin{array}{l}\text { Primary } \\
\text { school } \\
(\mathrm{n}=3)\end{array}$ & $\begin{array}{l}\text { Primary } \\
\text { school } \\
(\mathrm{n}=7)\end{array}$ & $\begin{array}{l}\text { Housewife } \\
(\mathrm{n}=9)\end{array}$ & $\begin{array}{l}\text { Tradesman } \\
(\mathrm{n}=2)\end{array}$ \\
\hline & $\begin{array}{l}\text { Between } \\
\text { the ages } \\
\text { of 30-40 } \\
(\mathrm{n}=2)\end{array}$ & $\begin{array}{l}40-50 \\
\text { years } \\
\text { old } \\
(\mathrm{n}=7)\end{array}$ & $\begin{array}{l}\text { Three } \\
\text { Children } \\
(\mathrm{n}=3)\end{array}$ & $\begin{array}{l}\text { Secondary } \\
\text { school } \\
(\mathrm{n}=2)\end{array}$ & $\begin{array}{l}\text { Secondary } \\
\text { school } \\
(\mathrm{n}=2)\end{array}$ & $\begin{array}{l}\text { Worker } \\
(\mathrm{n}=1)\end{array}$ & $\begin{array}{l}\text { Security } \\
(\mathrm{n}=1)\end{array}$ \\
\hline & $\begin{array}{l}40-50 \\
\text { years old } \\
(\mathrm{n}=5)\end{array}$ & $\begin{array}{l}\text { Above } \\
\text { Three } \\
\text { Children } \\
(\mathrm{n}=3)\end{array}$ & $\begin{array}{l}\text { No literacy } \\
(\mathrm{n}=2)\end{array}$ & $\begin{array}{l}\text { High School } \\
(\mathrm{n}=1)\end{array}$ & & \\
\hline & $\begin{array}{l}\text { Over } 50 \\
(\mathrm{n}=1)\end{array}$ & & & $\begin{array}{l}\text { Primary } \\
\text { school } \\
\text { dropout } \\
(\mathrm{n}=3)\end{array}$ & $\begin{array}{l}\text { Worker } \\
(\mathrm{n}=1)\end{array}$ \\
\hline & & & & & & \\
\hline & & & & $\begin{array}{l}\text { Farmer } \\
(\mathrm{n}=2)\end{array}$ \\
\hline
\end{tabular}

As seen in Table 1, when the ages of the mothers of the students are examined; $20 \%(\mathrm{n}=2)$ are between the ages of $20-30,20 \%(n=2)$ are between the ages of $30-40,50 \%(n=5)$ are between the ages of $40-50$ and $10 \%(n=1)$ are over the age of 50 . When the age range of the fathers is examined, $30 \%(n=3)$ are in the $30-40$ age range and $70 \%(n=7)$ are in the $40-$ 50 age range. When the number of children of the families is examined; $22 \%(n=4)$ have two children, $33 \%(n=3)$ have three children and $45 \%(n=3)$ have three children. Considering the educational status of the mother; $30 \%(n=3)$ were primary school graduates, $20 \%(\mathrm{n}=2)$ were secondary school graduates, $30 \%(\mathrm{n}=3)$ were primary school dropouts, and $20 \%(n=2)$ were illiterate. When the educational status of the fathers is examined; $70 \%(n=7)$ are primary school graduates, $20 \%(n=2)$ are secondary school graduates, $10 \%(\mathrm{n}=1)$ are high school graduates. When the professions of the mothers are 
examined, it is seen that $90 \%(\mathrm{n}=9)$ are housewives and $10 \%(\mathrm{n}=1)$ are workers. $20 \%(\mathrm{n}=2)$ of the fathers are tradesmen, $10 \%(n=1)$ are workers, $10 \%(n=1)$ are security, $20 \%(n=2)$ are farmers and $40 \%(n=4)$ are from other professions.

In order to better describe the parents included in the research group and to increase the validity and reliability of the research, the question of how to define yourself as a parent was asked to them. According to the answers received from this question, the parents' own definitions are as follows:

Table 2: Parents' Identification of Parents

\begin{tabular}{|l|l|}
\hline Mothers F & Fathers F \\
\hline Protecting 1 & Understanding 6 \\
\hline Caring 3 & Caring 2 \\
\hline Supporting 1 & Authoritarian 2 \\
\hline Authoritarian 2 & \\
\hline Obsessive 1 & \\
\hline Insightful 2 & \\
\hline
\end{tabular}

\subsection{Data Collection Tools}

Both interview and mind map techniques were used to increase the validity of the study. The study data were collected with a semi-structured interview form applied separately to parents and children and with the mind map technique applied to children. Two interview forms were used, the same for parents and separate for children. The interview form was prepared by the researchers by scanning the literature. In order to ensure the validity and reliability of the questions created in accordance with the sub-problems, expert opinions of 2 academicians working in the field were obtained. In line with expert opinions, the forms were finalized. As a pilot application of the interview form, a family consisting of a mother, father and child was interviewed. Thus, the suitability and comprehensibility of the forms were determined. 2 questions in the parent interview form and 1 question in the child interview form were rearranged. There are six questions in the parent interview form. The first of these questions was prepared to better describe the parents in the study group. There are five questions in the interview form prepared for children. At the same time, the mind map technique was used to confirm the interviews with children and to increase the validity of the research by diversifying the data collection tools.

Mind maps are maps created so that information structures can be seen and embodied as a whole. Mind maps enable the connections of a subject to be presented with colored pencils and a versatile scheme in a flexible way (Yumuşak, 2013). Since there is no limit to the ideas and the relationships to be established between words and there is no requirement to fit into a specific structure, mind mapping promotes creative thinking while also supporting brainstorming (Davies, 2011, cited in: Ekici, 2015). For this reason, mind maps allow individuals to go beyond the boundaries and reveal many positive or negative thoughts and opinions they have about a subject (Ekici, 2015). In the mind map technique, there is a concept or subject at the center. Individuals write down what they 
have in their minds about the concept in question and what they associate with them. They express their thoughts on the subject using symbols, colors and drawings with the help of arrows placed in the center. They explain the meaning of these in a short sentence.

\subsection{Data Collection Process}

Before collecting the data, the students were informed about the technique to be used. What the mind map technique is and how to do it are explained. The mind map technique introduced by the researchers continued with a sample application. After making sure that the students understood the technique, they were asked to prepare a mind map with their parents in the center. The data were collected by meeting with the students through the video interview program, Zoom. During the meeting, mind maps were prepared by the students. After the meeting, mind maps were delivered to the researchers digitally. The students were given 25 minutes to prepare the mind map. Questions from students about the applied technique were answered. During the application, students were not limited or directed.

In the other stage of data collection, individual interviews were made with both students and their families on zoom and WhatsApp. On the day and hour of the interview, the parents of the students were interviewed by phone in advance and an appointment was made. The interviews with the students lasted about 20 minutes on average. Interviews with parents lasted about 35 minutes on average. Parents were interviewed one after another but separately. Thus, it was studied to ensure that the responses were independent of each other. These interviews were completed in 15 days. Interviews with students and their parents were recorded. Students and their parents were previously informed and enrolled after their permissions were obtained. After the interviews, the interview records were written down.

\subsection{Analysis of Data}

The data obtained from the study were analyzed by content analysis. In content analysis, the goal is to achieve concepts and relationships that will help explain the data collected from research. The collected data should be conceptualized first and then a logical arrangement should be made in terms of the concept obtained. Then, it is necessary to reveal the themes that explain the data (Yıldırım and Şimşek, 2016). In order to make a more detailed examination, the data were evaluated by content analysis. The recorded interviews were written down so that the answers to the interview questions were first transferred to the Word file. Mothers are coded as A1, A2, A3... Fathers are coded as B1, B2, B3... Students are coded as Ç1, Ç2, Ç3... The data obtained were read repeatedly by the researchers and the codes were created first. Categories and finally themes were reached from the codes created. In order to reflect the views of the students and their parents clearly and fully, direct quotations were included and the findings were tried to be supported. The data obtained from the interview were coded by two separate researchers and consensus was reached to create compatible codes. 


\subsection{Validity and Reliability}

For the internal validity of the research, the opinions of the students and their parents were given with direct quotations. In order to determine the reliability of the data analysis, the reliability value was calculated with the formula proposed by Miles \& Huberman (1994) with two-week interval coding. In qualitative studies, the agreement between coders should be at least 85\% (Miles, Huberman and Saldana, 2014, p.79). The agreement for this research is $87 \%$.

\section{Findings}

In this section, the findings obtained as a result of the analysis made in the research are included. The findings were discussed under two headings in accordance with the subproblems of the research.

\subsection{Findings Related to the First Sub-problem}

Under this heading, the family relations that parents have established with their children and the school

Findings regarding their relationship are given in Diagram 1 below.

Diagram 1: Domestic Relationships with the Parent Eye

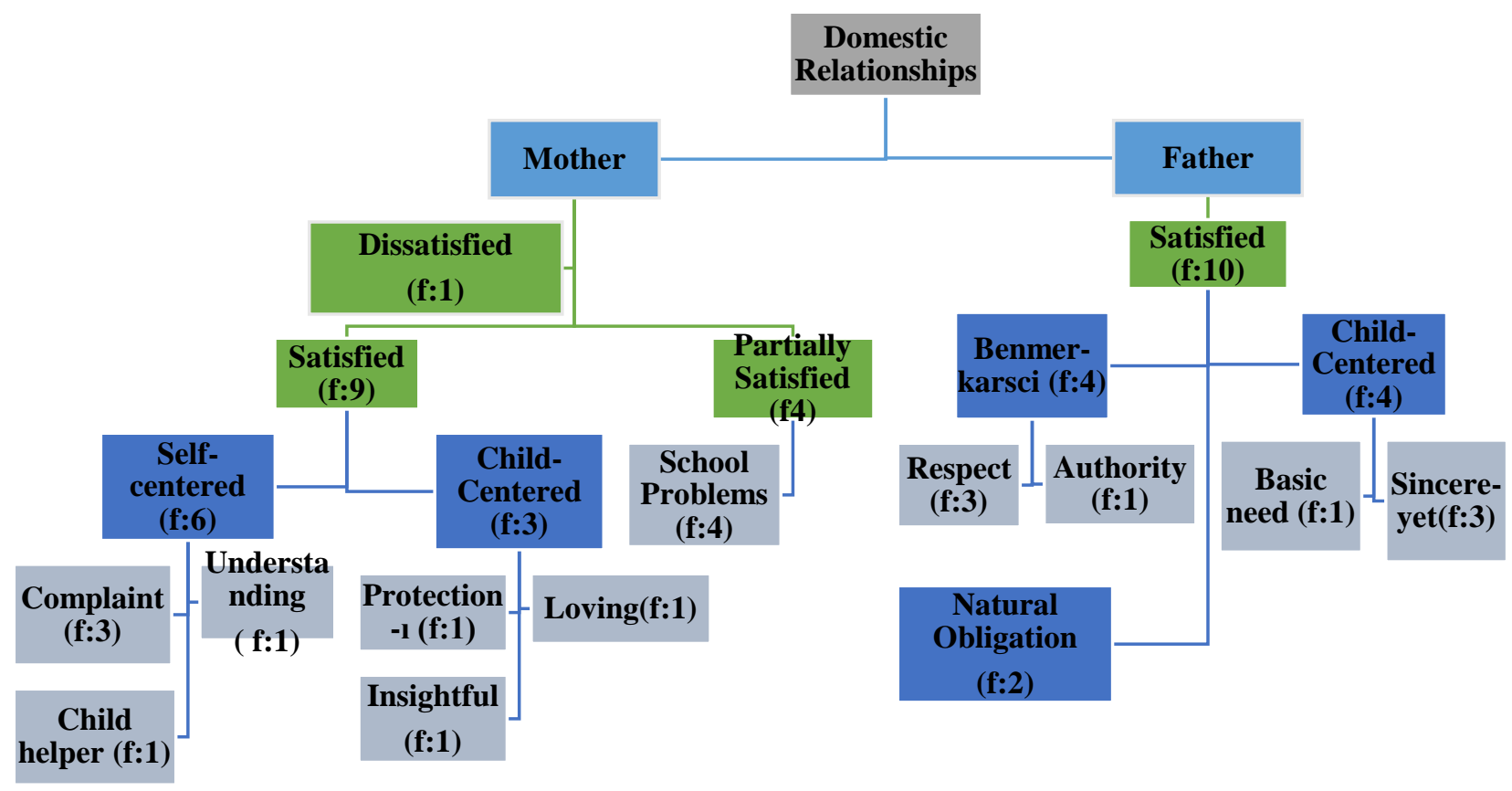

In Diagram 1, family relationships are discussed in terms of parents. Although nine of the mothers were satisfied with their relationship with their children, four of them stated that they had difficulties with their children about school issues and that they were not satisfied with their children. A mother is not satisfied with her relationship with her child. The tendency of mothers to be satisfied is gathered in two centers: Self-centered 
and child-centered. The self-centered category is coded as listening (f:3), understanding $(\mathrm{f}: 1)$ and child helper (f:1). Protective (f:1), loving (f:1) and understanding (f:1) codes formed the child-centered category.

Two predominant trends were observed in mothers' relationships with their children. Among the mothers, those in the egocentric category are those who focus on themselves in their relationship with their children and evaluate the relationship within the framework of the child's behavior towards them. Three of the mothers in this category are satisfied with their relationships because their children listen to them, one mother because her child helps them and one mother because her child is an understanding child. In the child-centered category, there are mothers who center the child in the relationship and evaluate their own behavior. A mother is satisfied with her relationship with her child because she has a protective attitude towards her child, one of the mothers is loving towards her child and one of the mothers is understanding towards her child. The mother, who was not satisfied with her relationship with her child, showed that this was due to her child's sibling jealousy and not listening to her own words. Excerpts from mothers are given below:

"So, I would be more satisfied if it was good but still better. In other words, I would be more pleased if he/she was loyal to his/her lessons, we would also be peaceful... " (A1)

"I'm not satisfied. Sometimes I question myself why. When I talk to others, he listens to me, my eldest son, for example, I have never had any problems with him. This is what happened after he became his very jealous little brother... " (A7)

"Yes. I'm glad I have a daughter like that because she's my child. He's easygoing, so he can understand you. It is small and small, big and big, I mean such a child. " (A9)

According to the diagram, all fathers are satisfied with their relationship with their children. Reasons for satisfaction are grouped into three categories: Self-centered (f:4), child-centered (f:4), and natural necessity (f:2). Just like mothers, self-centered fathers put themselves at the center of their relationships with their children and evaluate their children with their own behaviors. One of the fathers exhibits an authoritarian attitude, and three of them demonstrate their satisfaction with their relationships with their children because their children are respectful to them. Fathers in the child-centered category determine the direction of the relationship by putting the child in the center and evaluating their own behaviors. One of the fathers is satisfied with the relationship because he meets the basic needs of his child and three are satisfied with the relationship because he has a warm and sincere relationship with his child. Both fathers consider their relationship with their children in the context of a natural obligation. They stated that they were in any case satisfied with the relationship between them because of their child. Excerpts from fathers are given below: 
Yes, M. I thank God a thousand times for having a daughter. I'm glad my daughter respects me, loves me, and I love her. (B3)

Of course, I am. I'm glad it's my kid. (B4)

I am pleased. Because we have a warm family environment. Everyone is understanding and honest with each other. (B10)

The evaluation of the relationships between parents and their children in terms of school is shown in Diagram 2.

In Diagram 2, the school relationships that parents have established with their children are discussed in terms of parents under the categories of school problems and low grading. While mothers' school relationships with their children are coded as advising (f:3), dominant (f:1), passive (f:2) and active (f:4) in the school problems category, they are coded as reflecting (f:4), desperate (f:2) and reflective (f:4) in the low grade category. While the school relationships of fathers with their children were coded as passive (f:5), facilitator (f:1), active (f:2) and advisor (f:2) in the school problems category, they were coded as helpless (f:1), nonchalant (f:4), inspiring (f:3), reflecting (f:1) and questioning (f:1) in the low grade category.

Diagram 2: School Relations with Parental Eye

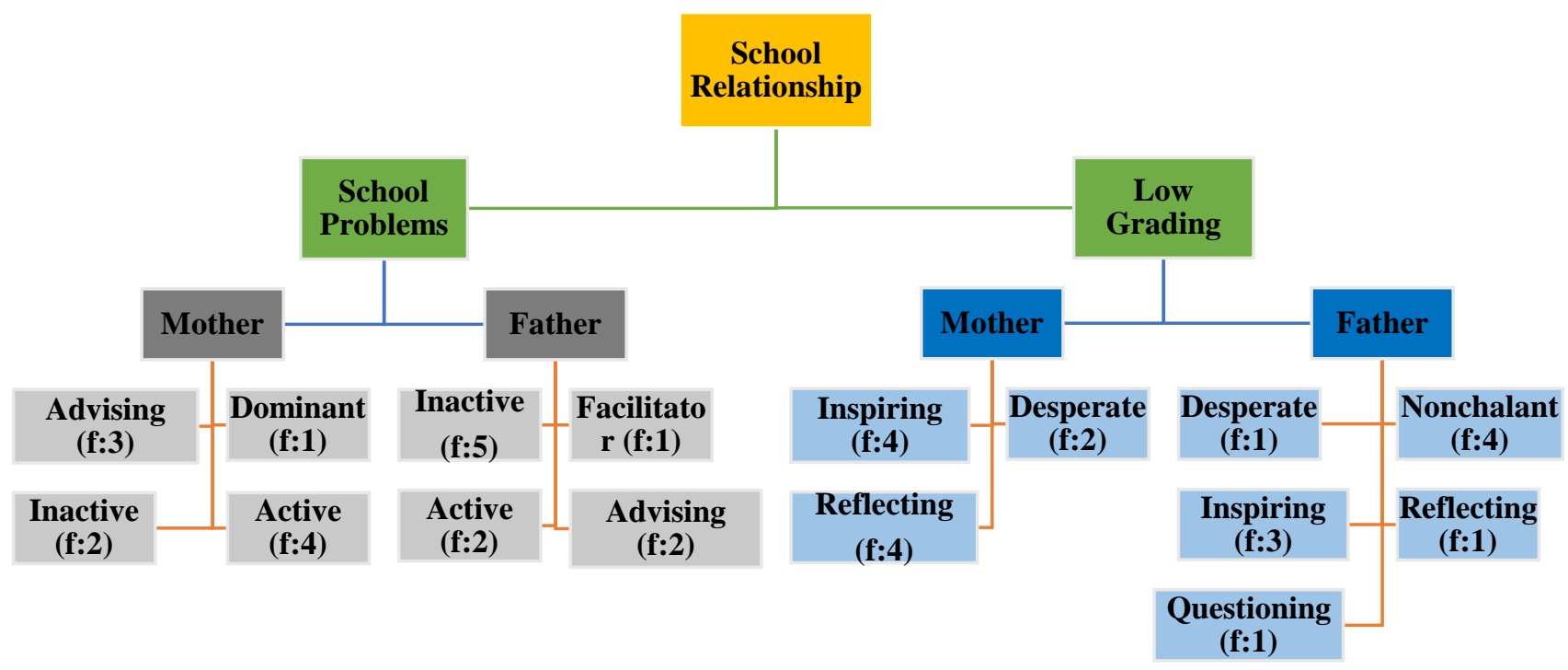

Considering the school relationships that mothers have established with their children, it was seen that some mothers played an active role in solving these problems in the face of a problem experienced at school. Some of the mothers exhibit an advisory attitude in the face of school problems. While two mothers remain passive in the face of 
problems, one mother acts dominantly with a slightly harsher attitude. The quotes of the mothers are given below:

"R. is very scared. It's like panic attack. I'm gonna take him to a psychologist. But for example, if there is a problem with his friends, I tell him to be good, to be good with your friends. Don't fight with anyone." (A1)

"His father says listen to your lessons. And I am telling him/her to listen to his/her lesson. I'm asking her sister to help him/her. I try to do as much as I can, but I can't do much because I don't have education myself. Maybe if I had education myself, I would have helped him/her with his/her lesson." (A3)

"First, I listen to my daughter, then I listen to the other side. But, if possible, I'd like the teacher to solve it. I get angry when I first hear it if my daughter is upset. Because I get angry at the other side since I know my daughter. Then I think. I talk to my daughter. If I need to talk to the other side, I would talk to them, but I would try to deal with the teacher first. I would tell the teacher that way." (A10)

In the face of school problems, most of the fathers remain passive by putting the responsibility on the mother. There are two fathers who play an active role in solving problems. While two of the fathers exhibit an advisory attitude, one father is indifferent to the problems. The following are quotations of fathers:

"He shows the first reaction because his first teachers call his mother. By reaction, I mean that she talks to her daughter and then comes to me. Her mother sees her teachers from time to time. My child does not want to listen to his/her lessons, he/she has no other problems..." (B5)

"I act like this, when T. comes to us and reflects an incident to us. I call his/her teacher first. Of course, they are both children, after all, I call his/her teacher, I see his/her teacher. So, I try to understand because children can make mistakes with each other. Sometimes they can be influenced by TVs, the Internet or social media and do a lot of different things. In other words, children can do such things as making sarcastic speeches against each other or putting each other off. Like I said, I'll call Professor D. first, ask him about his situation, ask him about the other side. It makes more sense for both sides to be heard." (B6)

When children get low grades, some of the mothers suggest their children to study. Some mothers reflect this to their children with their moods and movements when their children get low grades. Two mothers feel helplessness when their children get low grades and do not know what to do. The quotes of the mothers are given below: 
"I can't get angry anymore because I've been waiting. As a mother, every person wants their child to succeed, to read. Sometimes I wonder why you get low grades, if I am trying to build your future instead of me, there will be such conversations so that you too will try..." (A5)

"I'm always talking, trying to get him to see his own fault. He already admits his mistake, but he still gets so violent. For example, his brother is trying to help him, even the brother does not listen to him grudgingly." (A7)

"I get a little angry... I can be a little harsh sometimes. Then I get mad at myself, but I can react a little harshly at first. My voice is too loud. Of course, not to raise your hand. My voice is getting a little higher, and then, of course, I regret it. And I apologize if I have to. Girl, don't upset me, don't do it again, I couldn't control myself, the child understands. Of course, we sit and talk to each other." (A8)

Some fathers advise their children to study when their children get low grades, just like mothers. Some fathers do not care if their children get low grades. One of the fathers feels helpless in the face of his child's low grades and accepts this situation. While one of the fathers shows this to his child with his/her attitude and attitude when his/her child gets a low grade, a father exhibits an interrogative attitude about his/her child's low grade. The following are excerpts from interviews with fathers:

"I've never had a bad approach. There is nothing to do, I have a daughter who did not read it..." (B1)

"So far, I haven't reacted much. He had some discomfort. Therefore, we were seeing their teachers all the time, so I want them to fix it a little this year. Because there's nothing to react to. I don't want to pressure you. It's worse when I put pressure on it. He gets upset when I pressure him, and I can't stand it. I'm trying to solve it by talking." (B5)

"First of all, I will investigate why he/she got a low grade. Then I will talk to my daughter and tell her to work better next time." (B10)

The ways in which parents with low grades follow to solve this problem are visualized in the following diagram: 


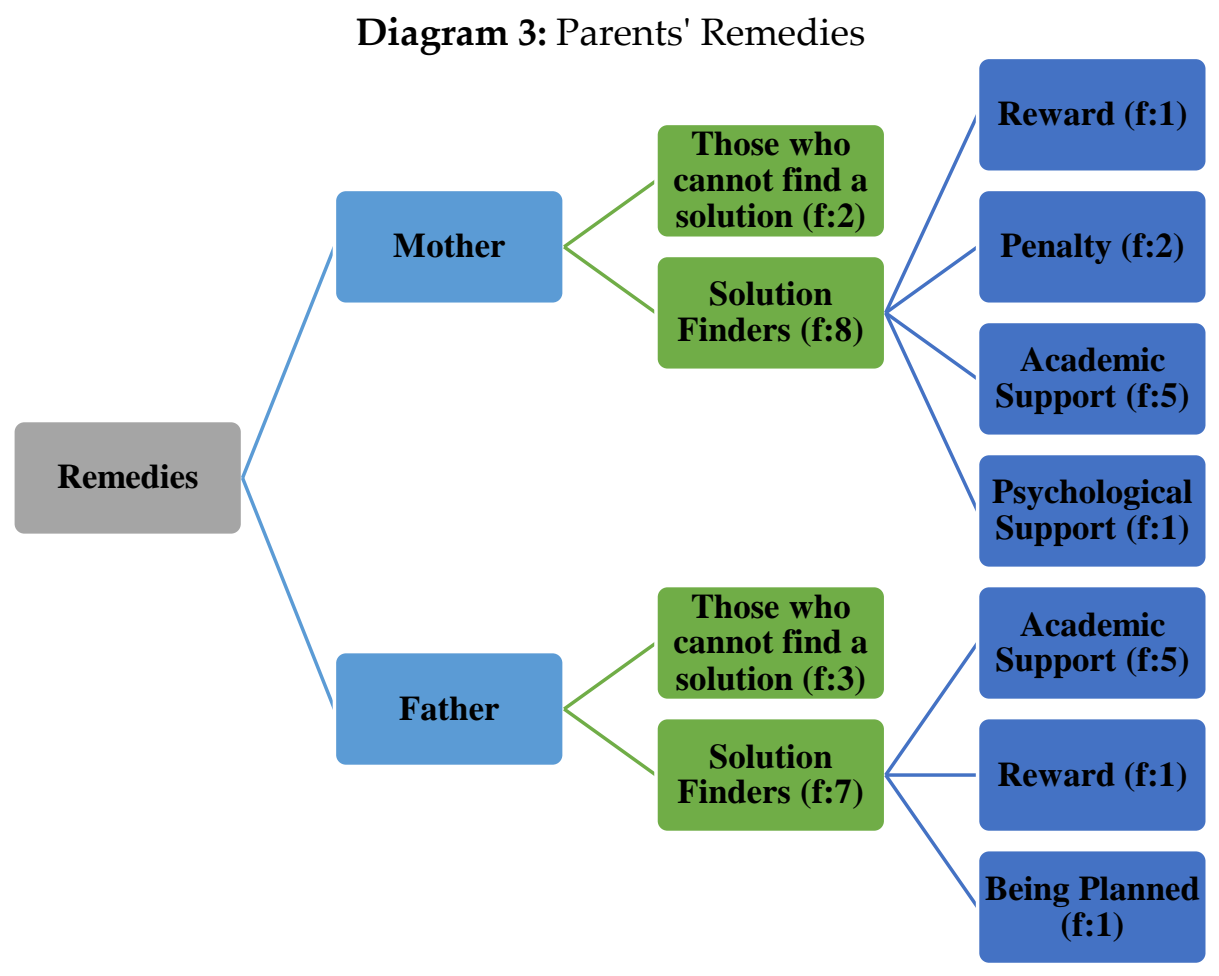

In Diagram 3, the solutions developed by the parents whose children had low grades to solve this problem were evaluated in terms of parents. Two of the mothers could not offer any solution to this situation. Those who found a solution among the mothers were coded as a reward (f:1), punishment (f: 2), academic support (f:5) and psychological support (f:1). While three of the fathers could not find a solution, those who found a solution among the fathers were coded with the names of academic support (f:5), reward (f:1) and being planned (f:1).

Some of the mothers whose children have low grades state that they can support their children academically to solve this problem. This support sometimes comes from a course, sometimes from a sourcebook, and sometimes from the children's own brothers and sisters. Two of the mothers said that they punished their children with low grades in order to solve this problem. A mother stated that she tried to support her child psychologically. The following are excerpts from interviews with mothers:

"I'm just saying, M. Look, don't get low grades, study hard, I'll be offended. I get angry. She loves playing with the baby with her friends. I forbid you to play with your friends, he doesn't listen." (A3)

"I looked for a solution, I took him to the doctor to see why you can't do it, why you feel sleepy. You know, if there's a distraction. The doctor said there was no problem. I said I also took him to the psychologist, he does not want to listen to lessons, he does not want to hear, he is focusing on something else, there is no problem..." (A5) 
"Of course, I'm looking for a solution. I'll try to get help. I'll help him with whatever class he's taking is low. If I can't do it, I will direct them to the courses from outside and make an effort." (A8)

Some of the fathers with low grades stated that they tried to support their children academically, just like mothers, to solve this problem. While a father encourages his child to correct his/her miscarriage grades by giving a reward to his/her child, a father advises his/her child to work regularly and in a planned manner. The following are excerpts from fathers related to this question:

"- Yeah. - Yeah. I usually say it to her sister. Since her sister is working well, help your sister or I am helping as much as I can. Bring me the lessons you can't solve, show me, show your sister. I don't know that much, but her sister is usually interested. It's because he's in high school. I usually tell him to help." (B3)

"Of course, I do. I don't remember what grade he was in, but we sent him to the course to make things better. We followed whatever kind of activities D. teacher was doing as much as we could." (B7)

"I'll look for solutions, yes. I'll tell him to make a show. I'll tell my daughter to work on a plan." (B10)

\subsection{Findings Related to the Second Sub-Problem}

In this section, the relationships that children establish with their parents are tried to be revealed in terms of children. In the following diagram, firstly, the general behaviors of parents towards children and the roles of children in this relationship are discussed.

In Diagram 4, family relationships were tried to be revealed in terms of children. In this direction, two categories were created as parental behaviors and the roles of children in the theme of family relations. Parental behaviors were examined in two subcategories as those who behaved well (f:9) and sometimes behaved well (f:1). Those who exhibit good behavior are coded as academic support (f:2), meeting requests (f:3) and lack of anger (f:5). The roles undertaken by children in family relationships are grouped under the category of children's roles. This category is coded as child helper (f:2), docile child (f:1), child outside (f:1) and child center (f:6). 


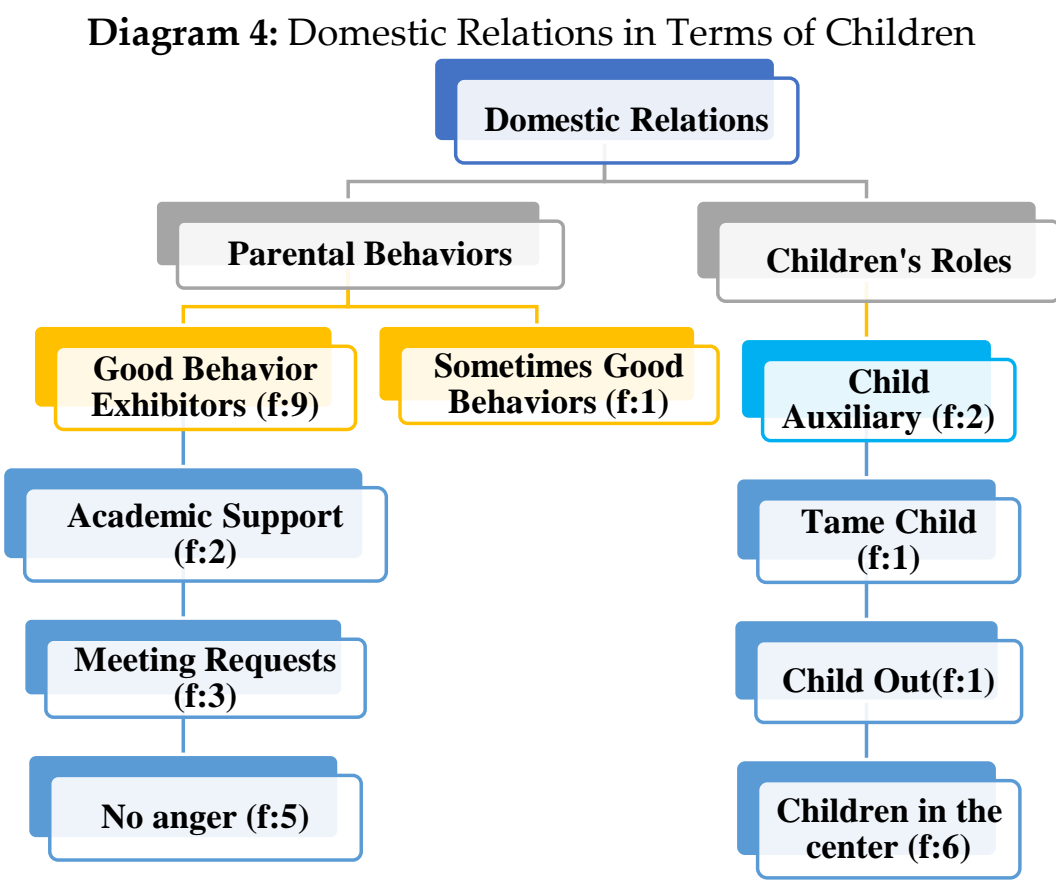

Other children than one child stated that their parents treated them well. Some of the children have justified their parents to be good to them by meeting their wishes. Some children think that their parents are nice to them because they are not angry with them. Both children justified good behavior by their parents helping them with the school. The child, who answered that they are sometimes good and sometimes they are bad, explained this situation because his parents were angry with him in some cases. Excerpts from children are given below:

"They're being nice. They're not mad at me. When I do something, they tell their friends to be nice. They say don't fight in school, take care of your lessons. When I do something bad, they tell me not to do it, they warn me." (Ç1)

"They're being nice. So, they're not doing anything bad. They take everything I want." (Ç3)

"Sometimes good, sometimes bad. They behave badly when I make mistakes. I piss them off sometimes. They get mad when I do something really bad. They get mad when I lie. They're nice to me when I get good grades. They're nice to me when I do something really good." (Ç7)

When the roles of children in their relationships with their parents are examined, it is seen that some children are seen as assistants, that is, they are in a position to help parents in their jobs. A child exhibits a docile structure that does not break the words of his/her parents. One of the children keeps himself/herself a little more out of the relationship with his/her parents. Most of the children are at the center of the relationship. 
They have an active process with their families. The statements of the children on the subject are as follows:

"I help my mother in the morning. I help my dad with the cows when he comes home from work. I bring weed to my father and my father gives it to me. My mom does the dishes, so I put them in the dishwasher. My mother and I fold my clothes..." (Ç1)

"My dad normally watches TV, my mom cleans. And sometimes Mom and Dad watch TV together. We watch it together too..." (Ç6)

"We'll do activities or something. You look at it on the Internet, you see pictures, paintings, drawings like this on paper. We'll watch a movie or something in the morning. I always do my lessons with your mother." (Ç8)

Where children are approved and disapproved in their relationship with their parents, they are visualized with the following diagram:

Diagram 5: Situations in which Children Obtain Parental Consent and Do Not Obtain Consent

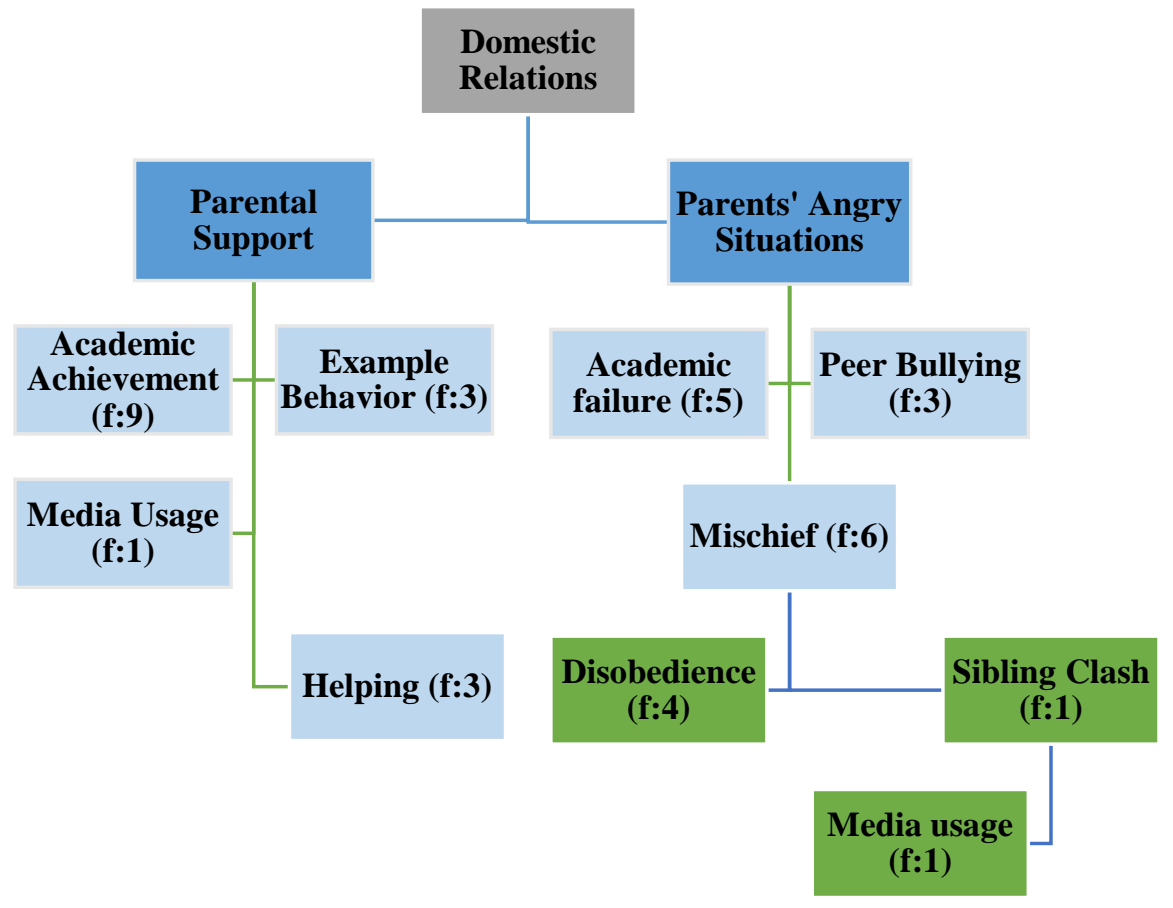

In Diagram 5, the situations in which the children were approved by their parents were grouped under the category of parental support; and the situations in which the parents were angry were grouped under the category of situations in which they were not approved. The parental support category is coded as academic achievement (f:9), exemplary behavior (f:3), media use (f:1) and helping (f:3). In the category of situations where parents are angry; academic failure (f:5), peer bullying (f:3) and mischief (f:6) codes 
are included. In order to make the code of mischief more explicit, this code is given in a little more detail: Disobedience (f:4), sibling conflict (f:1), and media use (f:1).

Most of the children are supported by their parents when they show academic success. Some children state that they are approved by their parents when they exhibit exemplary behavior such as fulfilling their responsibilities. Some of the children are approved when they help their parents in the house. A child receives parental support when he/she is controlled by media use. Quotes from children on the subject are as follows:

"For example, when I help my mother, when I go to the bakery with my father, they say well done to me and support me." (Ç2)

"... they support me on course topics, when I am not swearing, when I am not watching a lot of YouTube, or when I am studying. They say that I raised my daughter very well." (Ç6)

"...So when I get a good grade, they say well done to me. When I follow the rules, they say well done. Everyone has to make their own responsibilities at home." (Ç7)

Some of the children stated that their parents disapproved of them when they showed academic failure, did not do their homework and bullied their friends. Some of the children stated that their parents were angry when they misbehaved, that is, when they did not comply to their parents, when they experienced a sibling conflict when they used the media uncontrollably. Below are the views of children on the subject:

"When I fight with my brother, they get mad at me. Sometimes they get a little angry when I don't do my homework..." (Ç5)

"When I do not listen to my mother, when I get up for class, when I know wrong, when I get a low grade from the exam, they get angry..." (Ç8)

"Sometimes when I upset my mother, she gets angry. For example, if I do something that my mother tells me not to do, she will be upset..." (Ç10)

The table below shows the associations of children with their parents. This table was obtained by analyzing the mind maps prepared by the children: 


\begin{tabular}{|l|c|l|c|}
\hline \multicolumn{5}{c}{ Table 3: Parent Associations of Children } \\
\hline Code & Frequency (F) & Code & Frequency (F) \\
\hline Trust & 4 & Affection & 8 \\
\hline Longing & 2 & Mercy & 3 \\
\hline Heart & 2 & Togetherness & 4 \\
\hline Happiness & 4 & Joy & 2 \\
\hline Helpfulness & 2 & Courage & 1 \\
\hline Rules & 1 & Curiosity & 1 \\
\hline Friendship & 1 & Respect & 2 \\
\hline Favor & 1 & Responsibility & 1 \\
\hline Agree & 1 & Cuddle & 1 \\
\hline Work & 1 & & \\
\hline
\end{tabular}

According to Table 3, it is seen that the highest frequency in the associations of children with their parents belongs to the love code (f:8). Togetherness (f:4), trust (f:4) and happiness (f:4) were the most associated words after love. Children have made various associations with the mother and father. It can be said that the codes of rules (f:1), longing (f: 2 ) and responsibility (f:1) have a slightly more negative meaning for children. All other codes are positive associations. When children say parents, it is seen that they have values such as helping, responsibility and respect in their minds, as well as associations such as joy, courage, curiosity and happiness that will stimulate children's emotions.

When children's relationships with their parents are considered in the context of the school, the following scheme has been reached:

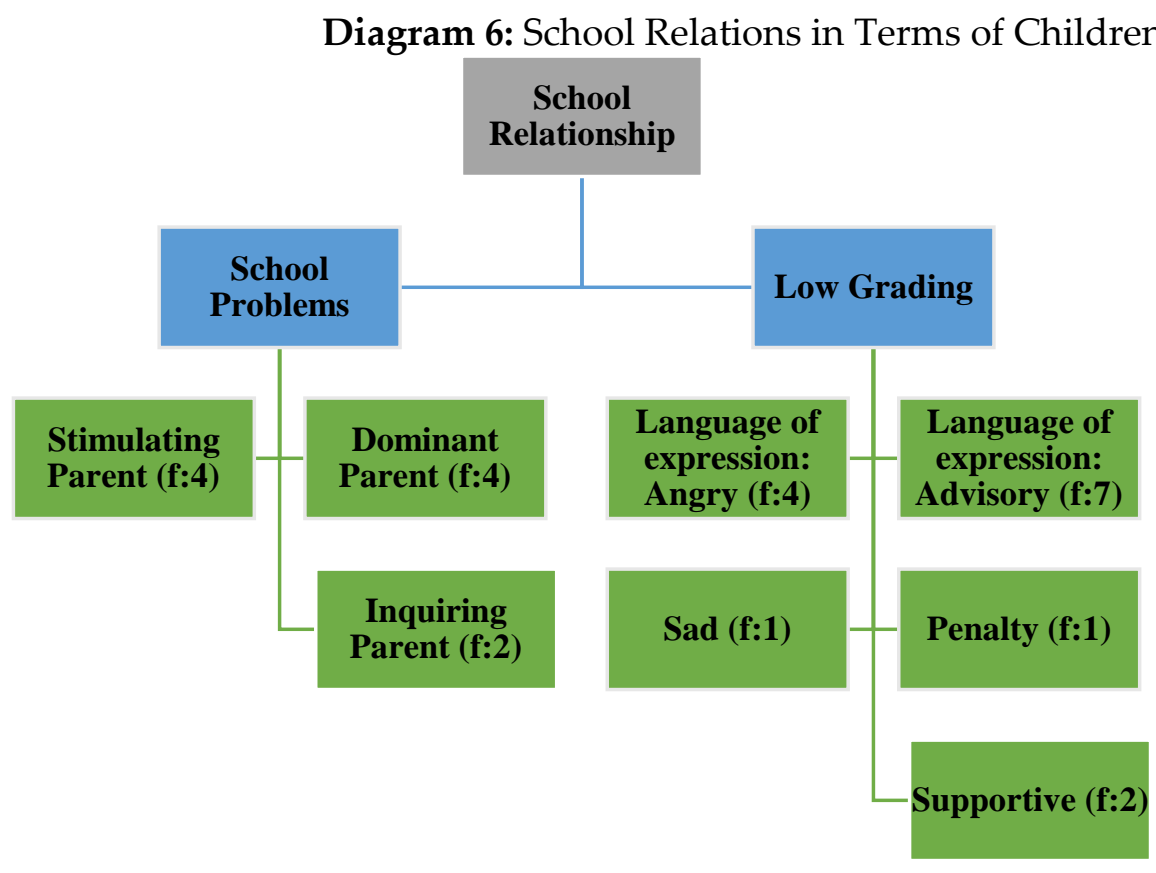

In Diagram 6, school relationships are grouped into school problems and low grading categories. School problems are coded as stimulating parent (f:4), dominant parent (f4) and questioning parent (f:2). If in the category of low grading; language of 
expression: angry (f:4), the language of expression: advisory (f:7), penalty (f:1), sad (f:1) and supportive (f:2) codes.

Some of the children state that their parents warn them when they have problems at school. Some of the parents can play a more dominant role and get angry with their children, squeeze them and direct them to apologize. On the other hand, two children stated that the parents exhibited an interrogative attitude in the problems at school. They mostly act to understand the problem. The views of the children on the subject are as follows:

"Sometimes they squeeze me to do a lot of homework. They get mad when I fight. They say, "Why did you fight?" They call it a fight." (Ç2)

"They say you should talk to your friend without fighting. They say you don't have to hit like that, you don't have to say swear words. Don't ever do that again. Be nice to your friends. Don't swear, don't fight. Apologize, say sorry." (Ç6)

"First, they listen to me, then they consult my teacher. If necessary, they will meet with the parent of the person who did it." (Ç10)

The vast majority of children stated that their parents advised them when they received low grades. Some children stated that their parents were angry when they received low grades. Two children said that their parents had a supportive attitude, while one said that their parents punished them when they got a low grade. One of the children stated that his parents were upset when he got a low grade. Excerpts from children are given below:

"They're giving advice. They say study. I study sometimes, too. When they don't study, they prohibit television and say study. Then I'm studying." (Ç3)

"My mom's raising her voice a little bit, and so is my dad. Then they forgive me. We study together." (Ç8)

"They get upset, but then we fix the bad things I do to get better grades. I can tell by their faces that they're sad. Their faces seem to be sad. They say you can do better, girl." (Ç10)

\section{Discussion and Conclusion}

This study was conducted to examine the relationships of children with low school success with their parents in the context of mother, father and child. When the relationships of mothers with their children were examined, it was seen that most of the mothers put themselves at the center of the relationship. Mothers evaluate their relationships with their children in the way their children treat them. If children listened 
and complied with their mothers, in other words, if they accept the authority of the mother, mothers are satisfied with their relationships with their children. One of the findings of the research supports this argument. The reason for the only mother who stated that she was not satisfied with her relationship with her child is that her child did not listen to her. In other words, it is the problem of not being able to establish an authority on the child. In fact, it can be said that most of the mothers evaluate the relationship in a unilateral context and rather than making a bilateral evaluation, they evaluate their children rather than the mother-child relationship. From this point of view, it can be stated that mothers do not need to think about their relationships with their children or do not have this level of consciousness.

It was concluded that fathers were more satisfied with their relationships with their children than mothers. One of the reasons for this situation is that mothers do not work except for one and fathers do. Therefore, it may be that children spend most of their time with mothers and less time with fathers. Another reason may be that the responsibilities of children are generally on mothers, the mother is the one who is in conflict with children, and the fathers are left out a little more. Soner (2000) also stated in his research that the mother is more effective than the father on the child's self-confidence and academic achievement. In the study, a significant relationship was found between maternal education and the self-confidence and academic success of the child.

Although fathers' answers are more diverse than mothers', it has been observed that similar tendencies are also in question for fathers. As mothers, some of the fathers evaluated their children with their own behaviors.

Considering the school relationships that mothers have established with their children, it is seen that some of the mothers remain passive in the face of problems experienced at school. The mother profile, which gives advice to the child and suggests, is drawn. From this point of view, an approach can be mentioned in which the problems experienced by the child at school are handled superficially and instead of producing, criticizing and evaluating solutions, the good and the bad are dictated to the child with customary stereotypes. Considering the solutions of mothers who have an active attitude towards problems, it can be said that they are not as effective as they think. It is seen that these mothers exhibit a more facilitative attitude and often expect the solution from the teacher. Considering the attitudes of fathers in the face of school problems, it is seen that they are more passive than mothers. Most fathers leave this responsibility to the mother. The mother who takes care of the child in every sense plays the role of parent who also takes care of school problems. This can be explained by the fact that fathers work long hours to make a living in the house. Considering the table containing the information about the fathers involved in this research, the basis of this opinion will be more clearly seen. Similarly, Argon and Kıyıcı (2012) stated in their study that parents' participation in education positively affects the success of children, but most of the parents do not actively participate in their children's education. Among the factors that prevent parents from participating in education, they have shown that their economic situation is bad, the intense work tempo of the working family and fatigue. 
As in school problems, when children get low grades, some of the mothers advise and advise their children to study. There are also mothers who feel helpless in the face of this situation. In fact, some mothers reflect this to their children with their moods and movements when their children receive low grades. They show that they are upset and angry. Although mothers are generally aware of their children's failures, they do not know what to do and how to act. One reason why especially mothers who feel helpless are in this situation can be sought in the inadequacy of their own education levels. Among these mothers are primary school graduates, mothers who have not completed primary school, and even mothers who are illiterate. It can be said that this situation is negatively reflected on children. Similarly, Aslan (1994), in his study examining the family factor in the success and failure of primary school students, concluded that the parents of successful students were high school and university graduates, their income levels were at medium and high levels, and they came from families with one or two children. Fidan (1996), on the other hand, found a high relationship between success and factors such as the socio-economic level of the family, the profession of the parents, and the level of education in his study aimed at determining the explanatory power of the environment in the differences in success and intelligence at school.

In this study, it was seen that similar situations could also apply to fathers. A father who works long hours and/or a father with a low level of education cannot support his child even if he/she wants to. Tatlican (1990), in his research conducted in secondary education institutions in Izmir, determined that the rate of staying in the classroom decreased as the income level of the family increased. Another finding of his research is that there is a direct relationship between father's education and classroom attendance. When the literature is examined, it is seen that there are also studies with a significant difference between the socioeconomic conditions of the families and the educational status of the parents and the readiness level of the child (Erkan, 2011; Aslanargun, Bozkurt, \& Sarıoglu, 2016; İpek, 2011). According to the research findings, 80percent of the students stated that the family had an effect on education, and the remaining 20 percent stated that the families were ineffective on education (Tatllloğlu \& Korkmaz, 2015).

In this study, it was revealed that some fathers did not care that their children got low grades. In his study on high school students, Dam (2008) concluded that the family affects the school success of the child and that the school success of students with family problems is lower than the school success of students who do not have family problems and receive support from their families. In other words, the indifferent attitudes of families towards their children and education can negatively affect the success of children. In their study, Akbaba-Altun (2009) reached a similar conclusion and emphasized parental indifference as the first reason for students to fail. ArendsKuenning and Duryea (2006) stated that parents' interest in their children's school situation has positive effects on their academic achievement.

Considering what parents with low grades did to solve this problem, it was concluded that two mothers and three fathers could not offer any solution. The reason 
for this is the inadequacies of education mentioned above. Even if these parents feel sorry for their children, unfortunately, they cannot go any further than giving them advice. On the contrary, children belonging to professional groups such as parents, teachers, faculty members, and civil servants may receive help from their parents in their learning processes and cause significant differences with other children (Vural, 2004). The majority of parents who developed a solution found the solution to support their children academically. If there are older siblings at home, some of the parents who do not consider themselves sufficient receive the help of these siblings. It has also been observed that parents who have the opportunity to take courses use this opportunity. It has been revealed that very few parents use punishment as a solution.

When the family relations are revealed in terms of children, the results are as follows: Other children than one child stated that their parents treated them well. Considering the reasons for children to evaluate their parents as good, it is seen that their wishes are met. In other words, children's parents consider them good because they buy or do what they want. It can be said to be a kind of pragmatist approach. In this case, it can be concluded that children are in a purely self-interesting period in terms of moral development. Since parents are not angry with children and do not show violence, this situation has emerged as another reason for children to put parents in the category of good parents. The child, who stated that children can sometimes behave well and sometimes badly, justified this by the fact that his/her parents sometimes resent him/her. In other words, it can be said that anger for children is one of the cornerstones in order to be a good parent. Kaya and Tuna (2010), in their research focusing on popular culture and the effect of the products of this culture on the family relationships of primary school children, concluded that although they described the relationship levels of children with their parents as good and very good, children complained that their parents were angry, confused and annoyed with them.

When the roles of children in their relationships with their parents are examined, it is seen that some children are seen as assistants, that is, they are in a position to help parents in their jobs. Most of the children stated that they were at the center of the relationship. They stated that they were going through an active process with their families and that they were doing various activities when they had the chance. The regions where they lived can be shown as the reason for this fundamental difference between children. Children who are considered as assistants live in more rural areas and their families provide their livelihoods through farming.

Most of the children are supported by their parents when they show academic success. Similarly, when they show academic failure, they are not approved by their families. It can be said that children are actually aware of their failure and the effects of this situation on their parents. This shows that there are roles attributed to children by their parents. If the child wants to be approved, he/she should demonstrate the expected behaviors. These behaviors include helping parents and fulfilling responsibilities. Other situations where children are not approved by their parents include peer bullying, disobeying parents, and misbehaving. In fact, it can be said that the parents subject to this 
study are generally prone to an authoritarian structure. Özabacı and Acat (2005) mentioned that parents with low socio-economic levels exhibit a slightly more repressive attitude to protect their children from the negativity of their living conditions and also due to their commitment to traditions, and this situation may negatively affect success. This view may also explain the authoritarian attitude of the parents involved in the study. Baumrind (1991), in his research, revealed that parents who exhibit democratic attitudes and behaviors behave more sensitively towards their children, show more love, convey their wishes to them, and allow their children to develop their interests. From this point of view, it can be said that when these children are approached with a similar attitude, it may be possible to experience positive developments for children.

According to the mind maps prepared by the children, it was concluded that the highest frequency in the associations of the children with their parents belonged to the love code. The concept of mother and father has made many associations in children, and most of these associations are positive. When children say parents, it is seen that they have values such as helping, responsibility and respect in their minds, as well as associations such as joy, courage, curiosity and happiness that will stimulate children's emotions.

Children stated that they received warnings from their parents about the problems they experienced at school. In fact, this result supports what parents say. Because as a result of interviews with many parents, it was seen that parents advised their children. Similarly, children stated that their families advise them when they receive low grades. There were also children who stated that their parents were angry when they got low scores. This coincides with what the parents say. It seems that parents do nothing but give advice and get angry about both school problems and low grades. It can be said that this situation is not sufficient for the solution of existing school problems and children's low grading problems. In general, there is no concrete behavior in parents that is put into action. It is possible to see this both in their own discourses and in children's discourses. However, when the opposite attitude is taken, that is, when parents take care of their children, talk about education, and make plans for their education together, it is found that their academic success increases and their problems such as skipping school decrease (Altschul, 2011; McNeal, 2014).

\section{Suggestions}

1) In order to prevent the school failure of the student, a number of initiatives can be made in the context of national education directorates, schools and teachers. Measures can be taken to prevent failures. In order to eliminate the failures that may be seen despite these measures, additional courses, home visits, etc. can be provided to the students within the directorate and school.

2) It can be ensured that families are informed about what they should do about student success, and for this purpose, family education can be carried out through the school. 
3) Students with low success can be supported to reinforce their lessons and do their homework from other students in the school within the framework of peer education.

4) The number of libraries where students can study inside and outside the school can be increased.

5) Studies can be carried out within provincial national education directorates and public education centers to support the development of children in disadvantaged regions.

\section{Conflict of Interest Statement}

There is no financial conflict of interest with any institution, organization or person related to our article. There is no conflict of interest between the authors.

\section{About the Authors \\ Merve Gül Seçgin is a PhD student at Istanbul University, Cerrahpaşa. She did her master's thesis on creative drama and self-determination theory. She works as a classroom teacher. orcid.org/0000-0001-8861-360X}

Şengül İlgar is graduated from Istanbul University, Department of Educational Sciences in 1990. She works at İ.Ü. Cerrahpaşa Hasan Ali Yücel Faculty of Education since 2000. Şengül İlgar, who received the title of Associate Professor in 2018, has made practical and theoretical studies in the fields of homework, motivation, measurement and evaluation, guidance, family education, technology since 1992 and has presented papers in national and international academic meetings, wrote articles in various journals and has some works done as book editor and book chapter writer. She gives classes in levels of bachelor's, master's and doctorate. İlgar, who has taken part in many domestic projects, gives many educations and seminars to families, teachers and grandparents due to projects and certificate programs.

\section{Bibliography}

Akbaba-Altun, S. (2009). İlköğretim öğrencilerinin akademik başarısızlıklarına ilişkin veli, öğretmen ve öğrenci görüşlerinin incelenmesi. İlköğretim Online, 8(2), 567-586.

Altschul, I. (2011). Parental involvement and the academic achievement of Mexican American youths: what kinds of involvement in youths' education matter most? Social Work Research, 35, 159-170.

Arcan K. (2006). Özel okullara giden lise düzeyindeki ergenlerin, akademik başarıları ile algıladıkları anne baba tutumları arasındaki ilişkilerin incelenmesi, Yüksek Lisans Tezi, İstanbul, Maltepe Üniversitesi.

Arends-Kuenning, M. ve Duryea, S. (2006). The effect of parental presence, parents' education, and household headship on adolescents' schooling and work in Latin America. Journal of Family and Economic Issues, 27(2), 263-286. 
Argon, T. ve Kıyıcı, C. (2012). İlköğretim kurumlarında ailelerin eğitim sürecine katılımlarına yönelik öğretmen görüşleri, Dicle Üniversitesi Ziya Gökalp Ĕ̆itim Fakültesi Dergisi, 19, 80-95.

Aslan F. G. (1994). İlkokul öğrencilerinin başarı ve başarısızlıklarında aile faktörü, Yüksek Lisans Tezi, Ankara, Hacettepe Üniversitesi SBE.

Aslanargun, E., Bozkurt, S. \& Sarığlu, S. (2016). Sosyo ekonomik değiş̧kenlerin öğrencilerin akademik başarısı üzerine etkileri, Uşak Üniversitesi Sosyal Bilimler Dergisi, 9(3), 214-234.

Baumrind, D. (1978). Parental disciplinary patterns and social competence in children. Youth and Society, 9, 239-276.

Carter, V., Good, E. (1973). Dictionary of education, New York: McGraw Hill Book Company.

Çelenk, S. (2003). Okul-Aile işbirliği ile okuduğunu anlama arasındaki ilişki, Hacettepe Üniversitesi Ĕ̆itim Fakültesi Dergisi, 24, 3-39.

Dam, H. (2008). Öğrencinin okul başarısında aile faktörü. Hitit Üniversitesi İlahiyat Fakültesi Dergisi, 2, 7(14), 75-99.

Dearing, E., Kreider, H., Simpkins, S., \& Weiss Heather, B. (2006). Family involvement in school and low-income children's literacy: Longitudinal association between and within families. Journal of Educational Psychology, 98, 653-664.

Driessen, G. Smith, F., \& Sleegers, P. (2005). Parental involvement and educational achievement. British Educational Research Journal, 31(4), 509-532.

Ekici, İ. D. (2015). Fen öğretmeni adaylarının bilime ilişkin algılarının zihin haritaları yoluyla belirlenmesi, Mehmet Akif Ersoy Üniversitesi Eğitim Fakültesi Dergisi, 34, 132 $-151$.

Erkan, S. (2011). Farklı sosyoekonomik düzeydeki ilköğretim birinci sınıf öğrencilerinin okula hazır bulunuşluklarının incelenmesi, Hacettepe Üniversitesi Eğitim Fakültesi Dergisi, 40, 186-197.

Erdoğdu, M. Y. (2007). Ana-baba tutumları ve öğretmen davranışları ile öğrencilerin akademik başarıları arasındaki ilişkiler. Sakarya Üniversitesi Eğitim Fakültesi Dergisi, 14, 33-46.

Eripek, S. (1982). Kuramsal açıdan çocuklardaki problem davranışların nedenleri ve bir sinıflandırma, Ankara Üniversitesi Eğilim Bilimleri Fakültesi Dergisi, 15(2), 35-46.

Fidan, N. (1996). Okulda Öğrenme ve Öğretme. İstanbul: Alkım Yayınevi.

Garbarino, J. (1985). Adolescent development: An ecological perspective. Columbus: Charles E. Merill.

Hakan, A. (2001). İlköğretim okulu öğrencilerinin başarısında aile faktörü, Yüksek lisans tezi, Sakarya, Sakarya Üniversitesi.

Kaya, K., \& Tuna, M. (2010). Popüler kültürün ilköğretim çağındaki çocukların aile içi ilişkileri üzerindeki etkisi, SDÜ Fen Edebiyat Fakültesi Sosyal Bilimler Dergisi, 21, 237-256.

Kızmaz, Z. (2004). Öğrenim düzeyi ve suç: suç- okul ilişkisi üzerine sosyolojik bir araştırma, Fırat Üniversitesi Sosyal Bilimler Dergisi,14(2), 291-319. 
McNeal Jr Ralph, B. (2014). Parent involvement, academic achievement and the role of student attitudes and behaviors as mediators. Universal Journal of Educational Research, 2(8), 564-576.

İpek, C. (2011). Velilerin okul tutumu ve eğitimine katılım düzeyleri ile aileye bağlı bazı faktörlerin ilköğretim öğrencilerinin seviye belirleme sınavları üzerindeki etkisi. Pegem Ĕ̆itim ve Öğretim Dergisi, 1(2), 69-79.

Özabacı, N., \& Acat, B. (2005). Sosyo ekonomik çevreye göre ilköğretim öğrencilerinin başarısızlık nedenleri, Eskişehir Osmangazi Üniversitesi Sosyal Bilimler Dergisi, 6(1), 145-169.

Pena Delores, C. (2000). Parent involvement: influencing factors and implications. The Journal of Educational Research, 94(1), 42-56.

Sarı, N. (12 Nisan 2012). Okul Başarısızlı̆̆1 http://bnposta.bingol.edu.tr/handle/20.500.12898/741, Erişim tarihi: 28.08.2021.

Soner, O. (2000). Aile uyumu, öğrenci özgüveni ve akademik başarı arasındaki ilişkiler, M.Ü. Atatürk Ĕ̆gitim Fakültesi Ĕ̆ilim Bilimleri Dergisi, 12, 249-260.

Şengönül, T. (2019). Anne-baba ilgisinin çocukların okul başarısı üzerindeki etkisi, Celal Bayar Üniversitesi Sosyal Bilimler Dergisi, 17(4), 268-292.

Tatlıcan, Ü. (1990). Ortaöğretimde başarı sosyo-ekonomik durum ilişkisi. Yüksek

Lisans Tezi, İzmir, Ege Üniversitesi, Sosyal bilimler Enstitüsü.

Tatlılıŏ̆lu, K., \& Korkmaz, G. (2015). İlköğretim öğrencilerinin okul başarılarını olumsuz etkileyen nedenlerin belirlenmesine yönelik bir araştırma (Konya örneği), Karatekin Edebiyat Fakültesi Dergisi (KAREFAD) 6(3), 93-116.

Tezcan, M. (1985). Okulda başarısızlık ve önlenmesi. Ankara Üniversitesi Eğitim Bilimleri Fakültesi Dergisi, 17(1).

Vural, B. (2004). Okul başarısında ailenin rolü ve önemi. İstanbul: Bilgi Yayınevi.

Yıldırım, A., \& Şimşek, H. (2016). Sosyal bilimlerde nitel araştırma yöntemleri. Seçkin Yayıncilık.

Yumuşak, G. K. (2013). Fen dersinde zihin haritalarının kullanımının öğrenci başarısına etkisi, Ĕ̆itim ve Öğretim Araştırmaları Dergisi,2(3), 1-5. 
Merve Gül Seçgin, Şengül İlgar

SOLUTION-ORIENTED EVALUATION OF FAMILY RELATIONS AND SCHOOL RELATIONS OF

CHILDREN WITH LOW SCHOOL SUCCESS IN THE CONTEXT OF PARENTS AND CHILDREN

Creative Commons licensing terms

Author(s) will retain the copyright of their published articles agreeing that a Creative Commons Attribution 4.0 International License (CC BY 4.0) terms will be applied to their work. Under the terms of this license, no permission is required from the author(s) or publisher for members of the community to copy, distribute, transmit or adapt the article content, providing a proper, prominent and unambiguous attribution to the authors in a manner that makes clear that the materials are being reused under permission of a Creative Commons License. Views, opinions and conclusions expressed in this research article are views, opinions and conclusions of the author(s). Open Access Publishing Group and European Journal of Education Studies shall not be responsible or answerable for any loss, damage or liability caused in relation to/arising out of conflicts of interest, copyright violations and inappropriate or inaccurate use of any kind content related or integrated into the research work. All the published works are meeting the Open Access Publishing requirements and can be freely accessed, shared, modified, distributed and used in educational, commercial and non-commercial purposes under a Creative Commons Attribution 4.0 International License (CC BY 4.0). 